\title{
IMPLEMENTASI MBTI UNTUK PENGEMBANGAN KARIR MAHASISWA: STUDI PERBEDAAN TIPE KEPRIBADIAN PADA MAHASISWA BIMBINGAN KONSELING
}

\author{
Farida Agus Setiawati, Agus Triyanto, dan Nanang Erma Gunawan \\ Universitas Negeri Yogyakarta \\ Email: faridaagus@yahoo.co.id
}

\begin{abstract}
Abstrak
Tujuan penelitian ini adalah untuk mengetahui tipe-tipe kepribadian individu dengan Myers-Briggs Type Indicator (MBTI) pada mahasiswa Bimbingan dan Konseling di Fakultas Ilmu Pendidikan, Universitas Negeri Yogyakarta. Di samping tipe kepribadian, penelitian akan mengukur kompetensi konselor yang dimiliki oleh para subjek. Tujuan berikutnya adalah mengetahui perbedaan kompetensi konselor berdasar berbagai tipe kepribadian. Data dikumpulkan dengan teknik survey dengan menggunakan dua instrumen yaitu MBTI dan kompetensi konselor yang sudah diadaptasi dari American School Counselor Association (ASCA) tahun 1992. Hasil menunjukkan subyek dengan tipe ekstrovert berjumlah lebih banyak daripada yang introvert, cenderung memperoleh informasi dengan sensing daripada intuisi, membuat keputusan dengan feeling daripada thinking, dan orientasi terhadap dunia luar yang relatif sama antar subyek penelitian. Pada kompetensi konselor, ada perbedaan rerata kompetensi pribadi pada subyek ekstrovert dan introvert ( $\mathrm{t}=3.602$ sig. $\mathrm{p}=.0 .000)$ dan pada kompetensi keterampilan ( $\mathrm{t}=2.167$ sig. $\mathrm{p}=0.031$ ). Sementara itu tidak ada perbedaan pada aspek pengetahuan dan professional yang mana juga nampak pada tipe kepribadian sensing dan intuition, thinking dan feeling, dan judging dan perceiving.
\end{abstract}

Kata kunci:Myers-Briggs Type Indicator, Kompetensikonselor, Mahasiswa Bimbingan dan Konseling

\section{IMPLEMENTING MBTI TO DEVELOP STUDENTS' CAREER: A STUDY OF PERSONALITY TYPES ON UNDERGRADUATE STUDENTS IN THE GUIDANCE AND COUNSELING STUDY PROGRAM}

\begin{abstract}
This research aims to investigate personality type and Counselor competence of undergraduate students in the Guidance and Counseling study program, Faculty of Education, Yogyakarta State University. A total of 209 students in the $4^{\text {th }}$ and $6^{\text {th }}$ semester completed two questionnaire, The Myers-Briggs Type Indicarot (MBTI) and a 1992 American School Counselor Association (ASCA) Competence Instrumen. Result shows that there are more subjects with focus preference of extrovertion, sensing in perceiving information, and feeling in making decision averagely. In terms of personal competency and skills, those subjects are different significantly for those who are extrovert and introvert ( $t=3.602$ sig. $p=.0 .000$ for personal competency and $t=2.167$ sig. $p=0.031$ for skills). There is no differences on knowledge and the degree of professional competence among involved subjects. How are personal competency and skills different significantly is discussed, mainly with psychosocial background and Western-adopted professional orientation issues.
\end{abstract}

Keywords: Myers-Briggs Type Indicator, Counselor Competence, Guidance and Counseling Students 


\section{PENDAHULUAN}

Berkembangnya layanan profesi Bimbingan dan Konseling di Indonesia telah dibersamai dengan bertambahnya jumlah orang yang berminat untuk menempuh studi pada program ini. Sebagai contoh, di Universitas Negeri Yogyakarta jumlah calon mahasiswa yang mendaftar pada program Bimbingan dan Konseling meningkat setiap tahunnya. Berdasarkan letak geografis, para mahasiswa yang telah terdaftar berasal dari berbagai daerah di seluruh Indonesia baik berasal dari sekitar kota Yogyakarta, atau dari luar kota bahkan dari luar pulau Jawa. Sebagai akibatnya, latar belakang demografi yang bervariasi pun dimiliki oleh mereka. Dari latar belakang yang berbeda, para mahasiswa tersebut tentu memiliki keunikan karakteristik yang bervariasi pula sehingga mereka akan mengalami dinamika pribadi yang berbeda-beda selama menjalani studi di Universitas Negeri Yogyakarta. Walaupun para mahasiswa memiliki latar belakang yang berbeda, mereka akan melewati serangkaian proses pendidikan dalam program Bimbingan dan Konseling yang sama dan merata. Mereka akan menempuh serangkaian proses belajar yang sama dan perlakuan yang sama untuk dipersiapkan menjadi guru Bimbingan dan Konseling di sekolah-sekolah atau biasa dikenal dengan sebutan konselor sekolah.

Dewasa ini, studi mengenai kepribadian konselor di Indonesia masih terbatas. Padahal, studi kepribadian konselor ini merupakan salah satu aspek penting untuk menentukan desain program pembelajaran dan memperkirakan luaran mahasiswa yang diharapkan. Kompetensi alumni dalam menyelenggarakan layanan konseling menjadi bagian perhatian utama untuk mengetahui kualitas lulusan program Bimbingan dan Konseling. Sebagai contoh, menurut Corey (2009:18) karakteristik konselor yang memiliki keterampilan interpersonal yang baik serta memiliki ketulusan dalam membantu orang lain dapat menghasilkan layanan konseling yang efektif. Selain itu, dalam Peraturan Menteri Pendidikan Nasional Republik Indonesia nomor 27 tahun 2008 tentang standar kualifikasi akademik dan kompetensi konselor, konselor diwajibkan memiliki kompetensi kepribadian selain kompetensi pedagogik, soial, dan professional. Maka dari itu, studi karakteristik kepribadian pada mahasiswa bimbingan dan konseling ini merupakan bagian penting dalam mematangkan kompetensi yang diamanatkan dalam peraturan menteri tersebut. Manfaat yang akan diperoleh

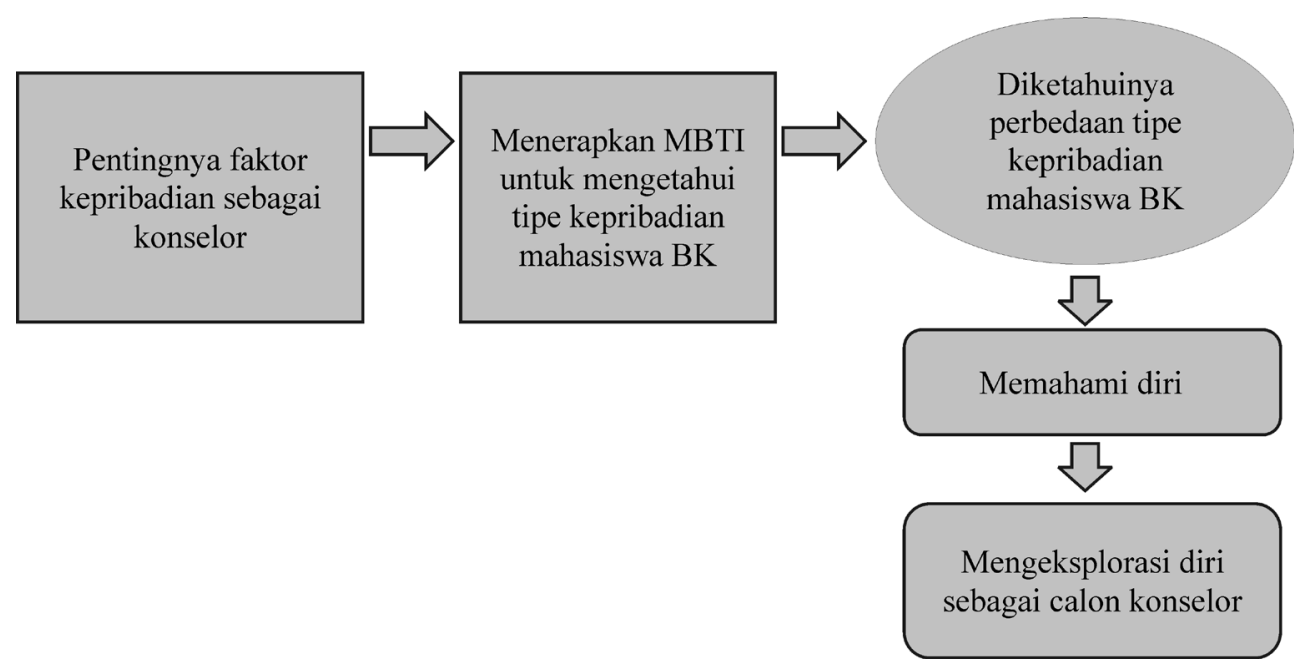

Gambar 1. Bagan dinamika berfikir alur penelitian 
dari penelitian ini adalah untuk mengetahui karakteristik kepribadian mahasiswa sehingga dapat digunakan mereka untuk memahami dan mengeksplorasi diri dalam rangka membangun kompetensi sebagai konselor sesuai dengan karakteristik kepribadian yang dimiliki. Berikut ini adalah bagan dinamika berfikir alur penelitian dapat dilihat pada gambar 1.

Salah satu instrumen yang sering digunakan untuk mengetahui karakteristik kepribadian adalah the Myers-Briggs Type Indicator atau dikenal dengan MBTI. MBTI telah dipahami dan digunakan secara luas untuk mengeksplorasi perbedaan kepribadian di berbagai bidang (Boyd \& Brown, 2005; Bradley \& Hebert, 1997) dalam bukunya yang berjudul Essentials of Myers-Briggs Type Indicator Assessment $2^{\text {nd }}$ Edition (Naomi L Quenk, 2009:2). Selain itu MBTI dikenal juga sebagai instrumen untuk mengukur tipologi kepribadian yang kemudian berfungsi untuk menjelaskan perbedaan kepribadian yang sehat. Instrumen ini dikembangkan berdasarkan teori Carl Gustav Jung tentang Psychological Types oleh Katharine Cook Briggs dan anaknya Isabel Briggs Myers (1995:7). Sekitar 2 juta orang tiap tahunnya menggunakan kuesioner MBTI sehingga instrumen ini dikenal secara luas dalam kapasitasnya untuk mengukur fungsi kepribadian yang normal. Alasan utama kepopuleran instrumen MBTI ini adalah kerelevansiannya dengan berbagai bidang seperti pendidikan, perkembangan karir, perilaku organisasi, fungsi kelompok, perkembangan tim, pelatihan pribadi dan eksekutif, psikoterapi inidividu, pasangan, dan keluarga, dan dalam konteks interaksi multikultural (Center for Applications of Psychological Type). Karena sejarah yang sangat panjang dan seringnya digunakan sebagai instrumen penelitian, pada tahun 2008 telah ada sekitar 11.000 tulisan yang terdaftar dalam bibliografi termasuk lebih dari 1.780 disertasi di dalamnya. Terlebih lagi, The Jurnal of Psychological Type telah mempublikasikan 69 volume yang berisi artikel tentang hasil-hasil penelitian tipologi MBTI. Pada tahun 2012, MBTI merupakan instrumen paling popular ke-2 yang digunakan oleh konselor sekolah di Amerika Utara setelah Beck Depression Inventory (Peterson et.al., 2014:92).

Berdasarkan pada kepopuleran dan kebermanfaatannya yang luwes sebagai sebuah instrumen pengungkap tipologi kepribadian bagi orang normal, MBTI memiliki kredibilitas yang kuat untuk mengetahui perbedaan tipe kepribadian pada mahasiswa jurusan Bimbingan dan Konseling Universitas Negeri Yogyakarta. Dengan demikian tujuan penelitian adalah 1) Mengetahui karakteristik kepribadian pada mahasiswa BK; 2) Mengetahui kompetensi konselor yang dimiliki mahasiswa BK; 3) Mencari keterkaitan karakteristik kepribadian dan kompetensi dasar konseling. Melalui penelitian ini, peneliti berharap dapat mengidentifikasi tipologitipologi kepribadian pada mahasiswa BK dan mengetahui kompetensi konselornya dan mengetahui keterkaitan diantara keduanya. Hasil identifikasi ini diharapkan akan dapat digunakan untuk mencari tipe kepribadian yang efektif untuk seorang konselor, sehingga dapat menjadi bahan masukan bagi mahasiswa sebagai dasar untuk mengembangkan diri.

\section{Myers-Briggs Type Indicator atau MBTI}

MBTI telah dikembangkan sejak perang dunia II oleh Katharine Cook Briggs. Pengembangan instrumen ini berlangsung cukup lama hingga 50 tahun dan dilanjutkan oleh Isabel Briggs Myers (Briggs-Myers \& Myers, 1995:6). MBTI merupakan sebuah instrumen untuk menggambarkan perbedaan mendasar perilaku manusia yang sehat dan normal. Instrumen ini dibuat berdasar teori tipologi dari Jung yang berpendapat bahwa ada empat fungsi psikologis mendasar pada manusia dalam berhubungan dengan dunia sekitarnya, yaitu: sensasi, intuisi,

Implementasi MBTI untuk Pengembangan Karir Mahasiswa: Studi Perbedaan Tipe Kepribadian ... 
perasaan, dan pemikiran (Briggs-Myers \& McCaulley, 1985:34).

Carl Jung dikenal sebagai salah satu teori yang tidak setuju dengan pendekatan psikoanalisis yang menjelaskan kepribadian sebagai sebuah fungsi dari dinamika dan dorongan ketidaksadaran yang mengendalikan perilaku dan pikiran. Melainkan, Jung dikenal sebagai seorang neo-psikoanalisis yang menempatkan manusia memiliki pola dasar ketidaksadaran yang merupakan kecenderungan untuk merespon lingkungan atau dunia dalam cara tertentu (MacLellan, 2011:1).

Pengembangan instrumen MBTI didasarkan pada perilaku sehari-hari manusia yang memiliki pola yang sama. Sebuah perilaku tidaklah muncul secara acak, namun cenderung berulang atau berkaitan dengan perilaku sebelumnya sehingga pada dasarnya perilaku manusia dapat diramalkan. Perilaku sehari-hari tersebut senantiasa terkait dengan fungsi psikologis mendasar sebagaimana dijelaskan oleh Jung. Fungsi psikologis yang mendasar inilah selanjutnya digunakan sebagai indikator pengembangan instrumen MBTI (Quenk, 2009:5).

Lebih lanjut Quenk (2009:5) menjelaskan bahwa kuesioner ini berisi 93 item, diisi sendiri oleh individu yang bersangkutan dengan pensil pada lembar jawab kertas yang disediakan. Isi dalam konstruk dikotomi tipologi-tipologi itu pun mencakup hal yang luas bukan sekedar terbatas pada aspek tunggal tipe kepribadian. Misalnya dalam dikotomi Extraversion-Intraversion bukan saja mencakup aspek sosialisasi tapi juga tingkat aktivitas, ekspresi, dan aspek lain yang membentuk konstruk tipologi ini. Jung berpendapat bahwa karakteristik perilaku manusia dapat dibedakan pada tipe preferensi. Perbedaan preferensi yang dibuat ini berdasarkan pada: 1) Tipe extrovert dan introvert yang merupakan arah pemusatan perhatian; 2) Sensing dan intuition, merupakan cara memperoleh informasi; 3) Thinking dan feeling merupakan cara membuat keputusan, dan 4) Judging dan perceiving merupakan orientasi terhadap dunia luar. Masing-masing tipe preferensi memiliki karakteristik tertentu. Gambaran keempat perbedaan tipe preferensi beserta penjelasan pada masing pasing tipe dapat dilihat pada tabel 1 berikut.

Tabel 1 menunjukkan beberapa tipe kepribadian dan gambaran tiap-tipe pada indikor yang dijelaskan. Berdasar berbagai indikator tersebut dibuatlah instrumen MBTI. Instrumen ini selanjutnya dikenal untuk mengukur tipe kepribadian seseorang (Boyd \& Brown, 2005:78; Bradley \& Hebert, 1997:346). Di samping itu, MBTI digunakan pula dalam bimbingan karir untuk mengetahui kecenderungan karir seseorang.

Mengetahui tipe kepribadian memiliki banyak keuntungan. Pengetahuan tipe kepribadian ini adalah komponen penting bagi seorang pendidik untuk memahami karakteristik siswa (Myers et al, 1998:64). Berdasar pemahaman tersebut, pendidik dapat memahami bahwa perbedaan adalah hal yang wajar, pendidik juga dapat mengidentifikasi kekuatan dan hal-hal yang bisa dikembangkan oleh siswa serta dapat memotivasi mereka berdasarkan karakteristik kepribadiannya. Pengetahuan adanya berbagai tipe kepribadian siswa juga membantu pendidik dalam melakukan proses pembelajaran dan strategi assesmen berdasar tipe kepribadian yang berbeda-beda.

Penelitian mengenai perbedaan tipe kepribadian berdasar teori MBTI telah dilakukan oleh MacLellan, Christin Reardon (2011:77) dengan meneliti perbedaan tipe kepribadian pada siswa di sekolah band, orkestra, dan paduan suara di sekolah tinggi Midwestern. Hasilnya menunjukkan adanya perbedaan karakteristik kepribadian siswa pada ketiga sekolah yang terlibat dalam penelitian. Ada perbedaan signifikan tipe kepribadian pada siswa orkestra dan paduan suara. Siswa paduan suara lebih ekstrovert dibanding siswa dari 
Tabel 1. Perbedaan Tipe Preferensi Kepribadian

\begin{tabular}{|c|c|c|}
\hline Dasar fungsi preferensi & Tipe Preferensi & Indikator tiap tipe \\
\hline \multirow[t]{2}{*}{ Arah pemusatan perhatian } & Ekstrovert (E) & $\begin{array}{l}\text { - Pendorong/energi utamanya adalah } \\
\text { lingkungan, dunia luar berupa orang lain } \\
\text { maupun benda } \\
\text { - Mengungkapkan keadaan emosi } \\
\text { - Membutuhkan hubungan antar pribadi }\end{array}$ \\
\hline & Introvert (I) & 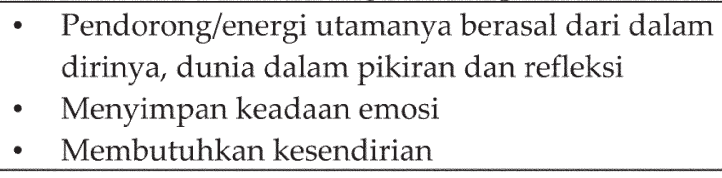 \\
\hline \multirow[t]{2}{*}{$\begin{array}{l}\text { Cara memperoleh } \\
\text { informasi }\end{array}$} & Sensing (S) & $\begin{array}{l}\text { - Mengumpulkan sesuatu melalui panca indera } \\
\text { - Melihat sesuatu yang rinci dan spesifik } \\
\text { - } \text { Mebih suka menangani hal hal yang praktis } \\
\text { - menikmani hidup untuk keadaan saat ini, } \\
\text { - Menyukai sesuatu yang nyata dan dapat diukur } \\
\text { - } \text { Oranyukai adanya prosedur } \\
\end{array}$ \\
\hline & Intuition $(\mathrm{N})$ & $\begin{array}{l}\text { - } \text { Mengumpulkan informasi dengan } \\
\text { - Menggunakan dugaan dan firasat } \\
\text { - } \quad \text { Lebih suka membayangkan kemungkinan yang } \\
\text { imajinatif } \\
\text { - Menjalani hidup untuk mengantisipasi masa } \\
\text { depan } \\
\text { - Menyukai berbagai kemungkinan untuk } \\
\text { berdaya cipta } \\
\text { - Menyukai variasi perubahan } \\
\text { Orang terkesan plinplan dan pemimpi bagi } \\
\text { orang S }\end{array}$ \\
\hline \multirow[t]{2}{*}{ Cara membuat keputusan } & Thinking (T) & 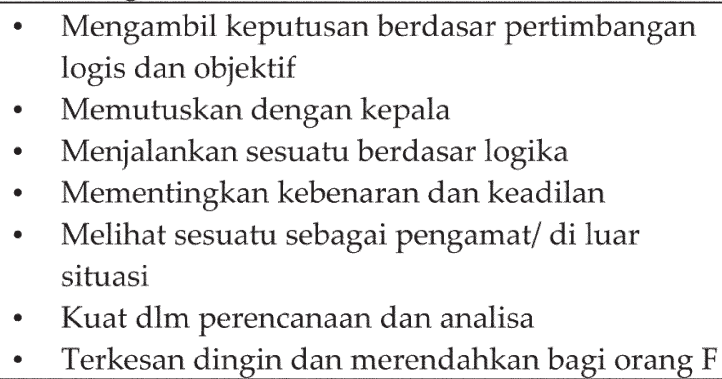 \\
\hline & Feeling $(\mathrm{F})$ & $\begin{array}{l}\text { - Mengambil keputusan berdasar pertimbangan } \\
\text { nilai pribadi yang subjektif } \\
\text { - Memutuskan dengan hati } \\
\text { - Menjalankan sesuatu berdasar keyakinan } \\
\text { - Mribadi } \\
\text { - Mementingkan hubungan dan keharmonisan } \\
\text { - Kangsung dalam situasi } \\
\text { - Terkesan berpikir tidak jelas \& emosional } \\
\text { sebagai orang T }\end{array}$ \\
\hline
\end{tabular}

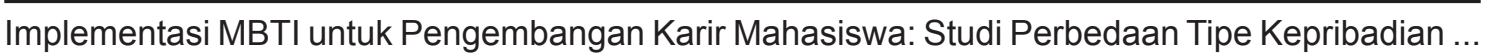




\begin{tabular}{|c|c|c|}
\hline \multirow[t]{2}{*}{$\begin{array}{l}\text { Orientasi terhadap dunia } \\
\text { luar }\end{array}$} & Judging (J) & $\begin{array}{l}\text { - } \text { Gaya hidup yang pasti terencana dan teratur } \\
\text { - Menikmati kondisi yang sudah ditentukan } \\
\text { - } \text { Menyukai batasan yang jelas dan kategori- } \\
\text { - } \quad \text { Merasa nyaman dalam situasi pasti/ada batasan } \\
\text { - Menangani deadline dengan merencanakan } \\
\text { sebelumnya } \\
\text { - Orang J terkesan menuntut, kaku, } \\
\text { gelisah/tegang bagi orang P }\end{array}$ \\
\hline & Perceiving $(\mathrm{P})$ & $\begin{array}{l}\text { - Gaya hidup yang luwes, spontan dan mudah } \\
\text { menyesuaikan } \\
\text { - Menikmati rasa ingin tahu, mendapatkan } \\
\text { kejutan } \\
\text { - Menyukai kebebasan dalam menjalani hidup } \\
\text { - Merasa nyaman dalam situasi terbuka } \\
\text { - Menghadapi deadline pada detik-detik terakhir, } \\
\text { - } \text { tergesa-gesa } \\
\text { - Trang P terkesan tidak terorganisir, } \\
\text { - Tidak bertanggung jawab bagi orang J }\end{array}$ \\
\hline
\end{tabular}

sekolah orkestra, sedangkan pada tipe-tipe kepribadian lain tidak ada perbedaan yang signifikan. Semua siswa pada tiap kelas cenderung memiliki tipe lebih intuitif dan feeling dalam cara memperoleh informasi dan membuat keputuan. Di antara ketiga kelas tersebut, siswa kelas band cenderung lebih luwes dalam berhadapan dengan dunia luar. Passmore, Holloway \& Rawle-Cope (2010:6) juga meneliti tipe kepribadian Pembimbing dan Konselor di London, United Kingdom. Hasilnya menunjukkan bahwa Pembimbing memiliki tipe kepribadian lebih intuitif dalam memperoleh informasi, ada perbedaan tipe dalam membuat keputusan pada Pembimbing dan Konselor, di mana kelas Pembimbing cenderung memiliki tipe kepribadian lebih mengacu pada pemikiran dalam membuat keputusan dibandingkan dengan perasaan.

\section{Kompetensi Konselor Sekolah}

Keberadaan konselor dalam sistem pendidikan nasional dinyatakan sebagai salah satu kualifikasi pendidik, sejajar dengan kualifikasi guru, dosen, pamong belajar, tutor, widyaiswara, fasilitator, dan instruktur (UU No. 20 Tahun 2003 Pasal 1 Ayat 6). Kesejajaran posisi ini tidaklah be- rarti bahwa semua tenaga pendidik itu tanpa keunikan konteks tugas dan ekspektasi kinerja. Demikian juga konselor memiliki keunikan konteks tugas dan ekspektasi kinerja yang tidak persis sama dengan guru. Hal ini mengandung implikasi bahwa untuk masing-masing kualifikasi pendidik, termasuk konselor, perlu disusun standar kualifikasi akademik dan kompetensi berdasar kepada konteks tugas dan ekspektasi kinerja masing-masing.

Dengan mempertimbangkan berbagai kenyataan serta pemikiran yang telah dikaji, bisa ditegaskan bahwa pelayanan ahli bimbingan dan konseling yang diampu oleh Konselor berada dalam konteks tugas "kawasan pelayanan yang bertujuan memandirikan individu dalam menavigasi perjalanan hidupnya melalui pengambilan keputusan tentang pendidikan termasuk yang terkait dengan keperluan untuk memilih, meraih serta mempertahankan karir untuk mewujudkan kehidupan yang produktif dan sejahtera, serta untuk menjadi warga masyarakat yang peduli kemaslahatan umum melalui pendidikan".

Sedangkan ekspektasi kinerja konselor yang mengampu pelayanan bimbingan dan konseling selalu digerakkan oleh motif altruistik dalam arti selalu menggunakan 
penyikapan yang empatik, menghormati keragaman, serta mengedepankan kemaslahatan pengguna pelayanannya, dilakukan dengan selalu mencermati kemungkinan dampak jangka panjang dari tindak pelayanannya itu terhadap pengguna pelayanan, sehingga pengampu pelayanan profesional itu juga dinamakan "the reflective practitioner". American School Counselor Association (Tahun 1990) menyebutkan kompetensi konselor sekolah ada 2 yaitu merujuk pada ciri-ciri pribadi konselor yang efektif dan kompetensi konselor itu sendiri yang meliputi kompetensi pengetahuan, kompetensi keterampilan dan kompetensi professional. Kompetensi konselor sekolah berdasarkan American School Counselor Association (1990) yaitu.

Konselor yang efektif merupakan sifat atau ciri pribadi konselor sekolah adalah sangat penting demi kesuksesannya. Konselor yang efektif biasanya 1) Mempunyai minat tulus terhadap kesejahteraan orang lain; 2) Mampu memahami pandangan orang lain;3) Mempercayai individu cakap memecahkan masalah; 4) Terbuka untuk belajar; 5) Bersedia mengambil resiko; 6) Mempunyai rasa kuat harga diri; 7) Tidak takut membuat kesalahan dan berusaha belajar dari kesalahan itu; 8) Menghargai pertumbuhan berlanjut sebagai seorang pribadi; 9) Peduli dan hangat; 10) Memiliki rasa humor.

Konselor sekolah harus tahu berbagai teori dan konsep (kompetensi pengetahuan) dan harus mampu menggunakan berbagai ketrampilan (kompetensi ketrampilan). Lebih lanjut, mereka harus sebagai profesional kompeten dan pribadi yang efektif. Kompetensi yang dibutuhkan oleh konselor pada saat ini yaitu konselor butuh mengetahui : 1) Teori dan konsep perkembangan manusia; 2) Teori-teori konseling individual; 3) Teori dan teknik konsultasi; 4) Teori dan teknik konseling keluarga; 5) Teori dan teknik konseling kelompok; 6) Teori dan teknik pembuatan keputusan karier; 7) Teori belajar; 8)
Teori motivasi; 9) Pengaruh budaya pada perkembangan dan perilaku individu; 10) Teori dan proses evaluasi; 11) Isu etika dan hukum; 12) Model pengembangan program.

Konselor sekolah harus mampu menampilkan keterampilannya dalam: 1) Mendiagnosis kebutuhan siswa; 2) Konseling individual; 3) Konseling kelompok; 4) Konsultasi dengan guru, siswa, dan orang tua; 5) Koordinasi program, misalnya testing pengembangan karier, penanganan narkoba; 6) Konseling karier; 7) Konseling pendidikan; 8) Mengidentifikasi dan melakukan rujukan yang tepat; 9) Mengadministrasi dan menginterpretasikan tes prestasi, minat, bakat, dan kepribadian; 10) Konseling lintas budaya; 11) Pembuatan keputusan etika; 12) Membangun suasana yang mendukung bagi guru dan siswa; 13) Menghilangkan dan/atau mengurangi bias suku dan jender dalam kebijakan dan kurikulum sekolah; 14) Menjelaskan ruang lingkup praktek dan fungsi konselor sekolah kepada guru, masyarakat, dan orang tua; 15) Merencanakan dan melaksanakan latihan dalam jabatan bagi guru; 16) Mengevaluasi keefektifan program konseling

Konselor sekolah harus memahami kompetensi professional untuk: 1) Melakukan evaluasi-diri untuk menentukan kekuatan mereka dan bidang-bidang yang memerlukan penyempurnaan; 2) Mengembangkan rencana pengembangan pribadi dan profesional untuk mendayakan mereka guna partisipasi dalam belajar seumur hidup; 3) Mengadvokasi hukum nasional; 4) Mengadopsi seperangkat kode etik profesi untuk membimbing praktek dan interaksi mereka dengan para siswa, guru, masyarakat, orang tua dan sebaya.

\section{METODE}

Pendekatan penelitian ini menggunakan pendekatan penelitian kuantitatif. Pendekatan kuantitatif ini merupakan pendekatan positivistik di mana penelitian ini dibangun berdasar sebuah teori

Implementasi MBTI untuk Pengembangan Karir Mahasiswa: Studi Perbedaan Tipe Kepribadian ... 
tertentu yang dijabarkan indikator dan instrumen penelitian. Ciri utama penelitian ini adalah menggunakan metode kuantitatif, di mana data-data hasil penelitian dapat dikuantitatifkan dan dapat dianalisis secara kuantitatif menggunakan analisis statistik.

Populasi dalam penelitian ini adalah mahasiswa Jurusan Bimbingan dan Konseling, Universitas Negeri Yogyakarta yang masih aktif kuliah. Sampel penelitian ini adalah beberapa mahasiswa BK dari berbagai angkatan yang diambil secara acak. Pengambilan data dilakukan dengan stratified random sampling, yaitu pengambilan sampel yang dilakukan berdasar tingkat kelas tertentu. Tingkat kelas dalam penelitian ini adalah angkatan awal hingga akhir yang ada pada Prodi BK. Pada Prodi BK tiap angkatan terdapat 3 kelas, di mana tiap-tiap kelas terdapat 40 hingga 50 mahasiswa. Penarikan sampel dilakukan pada satu sampel kelas di antara 3 kelas yang dipilih secara acak pada semester 1 dan 7.

Instumen penelitian ini menggunakan instrumen MBTI yang sudah diadaptasi di Indonesia. Spesifikasi instrumen MBTI ini mengacu pada tabel 1. Instrumen MBTI terdiri dari 3 bagian. Pada bagian 1 disebut sebagai Explorasi Pilihan Pribadi (EPP). Masing-masing tipe kepribadian dijelaskan dalam 7 butir, sehingga keseluruhan instrumen bagian 1 memiliki 28 butir. Pada bagian 1 disebut Instant Insight Inventory (III). Masing-masing tipe dijelaskan dalam 5 butir, sehingga terdapat 20 butir. Tiap butir pernyataan pada bagian 1 dan 2, terdiri dari 2 pernyataan di mana subjek penelitian diminta untuk memilih 1 diantara 2 pernyataan tersebut. Karena itulah, instrumen ini dikatakan sebagai instrumen preferensi. Bagian 3 instrumen ini disebut sebagai Self Select Form (SSF) yang merupakan penegasan pada tipe preferensi yang dipilih. Spesifikasi instrumen pada ketiga bagian dan penyebaran butir dapat dilihat pada tabel 2.

Instrumen MBTI sudah diadaptasi dan digunakan oleh beberapa tester, terutama yang bergabung dalam Himpunan Profesi Psikologi (HIMPSI), terutama yang berasal dari Jakarta dan sekitarnya. Sementara di Yogyakarta instrumen ini belum familier. Untuk itu instrumen penelitian dianalisis terlebih dahulu reliabilitas, setelah itu baru dilakukan analisis hasil penelitian. Reliabilitas instrumen tiap dimensi dihitung dengan formula alpha Cronbach. Karena instrumen penelitian ini mengukur multidimensi, reliabilitas secara keseluruhan dilakukan dengan reliabilitas komposit alpha berstrata. Hasil reliabilitas instrumen kompetensi konselor disajikan pada tabel 3.

Tabel 2. Spesifikasi Instrumen MBTI dan Penyebaran Butirnya

\begin{tabular}{|c|c|c|c|c|}
\hline \multirow{2}{*}{$\begin{array}{l}\text { Dasar fungsi } \\
\text { preferensi }\end{array}$} & \multirow{2}{*}{$\begin{array}{l}\text { Tipe } \\
\text { Preferensi }\end{array}$} & \multicolumn{3}{|l|}{ Number Butir } \\
\hline & & EPP & III & SSF \\
\hline \multirow{2}{*}{$\begin{array}{l}\text { Arah pemusatan } \\
\text { perhatian }\end{array}$} & Extrovert $(\mathrm{E})$ & 1A,5A,10A,15A,18A,21A,27A & $1 \mathrm{~A}, 2 \mathrm{~A}, 3 \mathrm{~A}, 4 \mathrm{~A}, 5 \mathrm{~A}$ & $\mathrm{E}$ \\
\hline & Introvert (I) & 1B,5B,10B,15B,18B,21B,27B & 1B,2B,3B,4B,5B & 1 \\
\hline \multirow{2}{*}{$\begin{array}{l}\text { Cara } \\
\text { memperoleh } \\
\text { informasi }\end{array}$} & Sensing $(S)$ & $2 \mathrm{~A}, 7 \mathrm{~A}, 9 \mathrm{~A}, 16 \mathrm{~A}, 20 \mathrm{~A}, 23 \mathrm{~A}, 28 \mathrm{~A}$ & 6A,7A,8A,9A,10A, & $S$ \\
\hline & Intuition (N) & 2B,7B,9B,16B,20B,23B,28B & $6 \mathrm{~B}, 7 \mathrm{~B}, 8 \mathrm{~B}, 8,10 \mathrm{~B}$ & $\mathrm{~N}$ \\
\hline \multirow[t]{2}{*}{$\begin{array}{l}\text { Cara membuat } \\
\text { keputusan }\end{array}$} & Thinking $(\mathrm{T})$ & 4A,6A,10A,13A,19A,24A,25A & $\begin{array}{l}\text { 11A,12A,13A,14A,15 } \\
\mathrm{A}, 16 \mathrm{~A}\end{array}$ & $\mathrm{~T}$ \\
\hline & Feeling (F) & 4B,6B,10B,13B,19B,24B,25B & 11B,12B,13B,14B,15B & $\mathrm{F}$ \\
\hline \multirow{2}{*}{$\begin{array}{l}\text { Arah pemusatan } \\
\text { perhatian }\end{array}$} & Judging $(\mathrm{J})$ & 3A,8A,12A,14A,17A,22A,26A & 16A,17A,18A,19A,20A & $\mathrm{J}$ \\
\hline & Perceiving $(\mathrm{P})$ & 3B,8B,12B,14B,17B,22B,26B & 16B,17B,18B,19B,20B & $\mathrm{P}$ \\
\hline
\end{tabular}

JURNAL PENELITIAN ILMU PENDIDIKAN, Volume 8, Nomor 2, September 2015 
Tabel 3. Reliabilitas Instrumen MBTI

\begin{tabular}{lcc}
\hline Dimensi & SD & Reliabilitas \\
\hline $\begin{array}{l}\text { Arah pemusatan } \\
\text { perhatian }\end{array}$ & 1,514 & 0,791 \\
$\begin{array}{l}\text { Cara memperoleh } \\
\text { informasi }\end{array}$ & 1,337 & 0,741 \\
$\begin{array}{l}\text { Merupakan cara } \\
\text { membuat keputusan }\end{array}$ & 1,523 & 0,785 \\
$\begin{array}{l}\text { Orientasi terhadap } \\
\text { dunia luar }\end{array}$ & 1,603 & 0,825 \\
Komposit & 3,346 & 0,831 \\
\hline
\end{tabular}

Hasil uji reliabilitas instrumen MBTI dengan menggunakan rumus alpha untuk reliabilitas tiap dimensi menunjukkan semua dimensi memiliki reliabilitas diatas 0.7. Hasil analisis ini menunjukkan instrumen MBTI cukup stabil pada hasil pengukuran.

Kompetensi konselor mahasiswa BK diukur dengan instrumen kompetensi konselor hasil adaptasi dari instrumen yang sudah dikembangkan oleh American School Counselor Association (ASCA). Kompetensi konselor meliputi kompetensi pengetahuan, kompetensi keterampilan dan kompetensi professional. Spesifikasi instrumen kompetensi konselor disajikan pada tabel 4 .

Tabel 4. Spesifikasi Instrumen Kompetensi Konselor

\begin{tabular}{ll}
\hline Dimensi & Butir \\
\hline Kompetensi Kepribadian & $1-10$ \\
Kompetensi Pengetahuan & $11-22$ \\
Kompetensi Keterampilan & $23-38$ \\
Kompetensi Profesional & $39-42$ \\
\hline
\end{tabular}

Uji instrumen dilakukan untuk menganalisis reliabilitas instrumen kompetensi konselor. Hasil analisis menunjukkan semua dimensi pada instrumen kompetensi konselor memiliki reliabilitas yang bagus atau di atas 0.8 , baik pada reliablitas tiap dimensi maupun reliabilitas komposit atau reliabilitas instrumen.
Tabel 5. Reliabilitas Instrumen Kompetensi BK

\begin{tabular}{llc}
\hline \multicolumn{1}{c}{ Dimensi } & \multicolumn{1}{c}{ Varian } & Reliabilitas \\
\hline Kompetensi Kepribadian & 30,802 & 0.865 \\
Kompetensi Pengetahuan & 68,420 & 0.926 \\
Kompetensi Keterampilan & 136,387 & 0.950 \\
Kompetensi Profesional & 10,403 & 0.890 \\
Komposit & 615,890 & 0.972 \\
\hline
\end{tabular}

Pengambilan data dilakukan dengan teknik survey, yaitu pengambilan data yang dilakukan tidak secara langsung tapi menggunakan suatu instrumen tertentu seperti angket, kuesioner, dan instrumen soal/tes. Pada penelitian ini instrumen MBTI diberikan pada mahasiswa BK semester 4 dan 6 untuk diisi dan dikembalikan lagi pada peneliti. Pengambilan data dilakukan setelah selesai perkuliahan .

Data yang sudah terkumpul dianalisis secara diskriptif dan inferensi. Analisis diskriptif dilakukan untuk mengetahui kecenderungan tipe kepribadian pada tiap kelas. Sedangkan analisis inferensi atau uji $t$ dilakukan untuk mengetahui perbedaan kompotensi konselor berdasar tipe kepribadian yang berbeda. Analisis uji t dilakukan dengan bantuan program komputer SPSS.

\section{HASIL DAN PEMBAHASAN}

Subyek dalam penelitian ini adalah mahasiswa jurusan Bimbingan dan Konseling, Fakultas Ilmu Pendidikan, UNY yang sedang berada pada semester empat dan semester enam. Instrumen Myers-Briggs Type Indicator dan instrumen kompetensi konselor dari American Counseling Association tahun 1992 diberikan kepada 209 mahasiswa jurusan Bimbingan dan Konseling FIP UNY. Hasil analisis diskriptif ditunjukkan pada tabel 6 .

Hasil Penelitian menunjukkan karakteristik kepribadian tipe ekstrovert berjumlah lebih banyak $(\mathrm{N}=125)$ dibandingkan yang introvert $(\mathrm{N}=84)$. Subyek yang lebih 
Tabel 6. Deskripsi Tipe Kepribadian Subjek Penelitian

\begin{tabular}{llll}
\hline \multirow{2}{*}{ Arah pemusatan perhatian } & & Jumlah & Persentasi \\
\hline & Ekstrovert & 131 & 60,9 \\
\cline { 2 - 4 } Cara memperoleh informasi & Introvert & 84 & 39,1 \\
\hline & Sensing & 160 & 74,4 \\
\cline { 2 - 4 } & Intuition & 55 & 25,6 \\
\hline \multirow{2}{*}{ Cara membuat keputusan } & Thinking & 82 & 38,1 \\
\cline { 2 - 4 } Orientasi terhadap dunia luar & Feeling & 133 & 61,9 \\
\cline { 2 - 4 } & Judging & 104 & 48,4 \\
\hline
\end{tabular}

cenderung memperoleh informasi dengan sensing lebih banyak (160) dibandingkan mereka yang menggunakan intuition $(\mathrm{N}=55)$. Dilihat dari cara membuat keputusan, subyek yang menggukan feeling berjumlah lebih banyak $(\mathrm{N}=133)$ dibandingkan dengan mereka yang menggunakan thinking ( $\mathrm{N}=82)$. Lebih lanjut, orientasi terhadap dunia luar nampak hampir seimbang diantara subyek yang terlibat dalam penelitian. Sebanyak 104 subyek cenderung judging dan 111 perceiving dalam berorientasi dengan dunia luar. Dengan demikian secara umum tipe kepribadian mahasiswa BK adalah ekstrovert, sensing, feeling dan perceiving.

Gambaran data kompetensi kepribadian dilihat pada tabel 7. Hasil tersebut menunjukkan gambaran kecenderungan sentral, yaitu rerata, median, modus, serta variasi skornya yang ditunjukkan dari standart deviasi dan variannya.

Hasil uji perbedaan tipe kepribadian dengan kompetensi konselor menunjukkan bahwa ada perbedaan rerata kompetensi pribadi pada subjek ekstrovert dan introvert, $\mathrm{t}=3.602$ dan signifikansi $(\mathrm{p}=0.000)$. Di samping kompetensi kepribadian, perbedaan rerata juga terjadi pada kompetensi keterampilan dengan $\mathrm{t}=2.167$ dengan signifikasi $p=0.031$. Sementara pada kompetensi pengetahuan dan professional tidak ada perbedaan. Tidak adanya perbedaan pada kompetensi konselor ini juga terlihat dari pada tipe kepribadian sensing dan intuition, thinking dan feeling, dan judging dan perceiving.

\section{Pembahasan}

Menurut Permen Pendidikan Nasional nomor 27 tahun 2008 tanggal 11 Juni 2008, lingkup tugas konselor mencakup pada kawasan pelayanan untuk mengembangkan potensi, memandirikan klien dalam membuat keputusan untuk mencapai kehidupan yang produktif, sejahtera, dan peduli pada kemaslahatan umum. Lebih lanjut, dalam permen itu juga dijelaskan kualifikasi untuk dapat memberikan layanan yang profesional. Salah satu syarat kompetensi konselor adalah kompetensi akademik yang meliputi: 1) memahami secara mendalam konseli yang dilayani, 2) menguasai landasan dan kerangka teoretik bimbingan dan konseling, 3) menyelenggarakan pelayanan bimbingan dan konseling yang memandirikan, dan 4) mengembangkan pribadi dan profesionalitas konselor secara berkelanjutan.

Kualitas kompetensi akademik yang dimiliki konselor sangat mempengaruhi kinerja konselor di mana sikap, nilai, dan kecenderungan pribadi yang mendukung akan melandasinya dalam pengembangan diri. Faktor kepribadian menjadi satu kesatuan dengan kompetensi akademik, kompetensi pedagogik, sosial, dan profesional yang mana kesemuanya terintegrasi dan membentuk profesionalitas karir seorang konselor. 
Tabel 7. Kompetensi Dasar Konselor Mahasiswa Bk

\begin{tabular}{lllll}
\hline & Pribadi & Pengetahuan & Keterampilan & Profesional \\
\hline $\mathrm{N}$ & 215 & 215 & 215 & 215 \\
Mean & 29,9209 & 29,9302 & 39,7256 & 9,3395 \\
Median & 31,0000 & 30,0000 & 41,0000 & 10,0000 \\
Mode & 32,00 & 28,00 & 41,00 & 10,00 \\
Std. Deviation & 5,54997 & 8,27166 & 11,67848 & 3,22535 \\
Variance & 30,802 & 68,420 & 136,387 & 10,403 \\
Skewness & $-2,328$ &,- 136 &,- 444 &,- 658 \\
Std. Error of Skewness & 0,166 & 0,166 & 0,166 & 0,166 \\
Kurtosis & 10,256 &,- 488 & 0,062 & 0,493 \\
Std. Error of Kurtosis & 0,330 & 0,330 & 0,330 & 0,330 \\
\hline
\end{tabular}

Pada hasil penelitian ini, ada beberapa hal yang menarik untuk dibahas. Pertama, hasil menunjukkan bahwa ada perbedaan kompetensi pribadi konselor dan kompetensi keterampilan berdasar pada arah pemusatan perhatian. Subyek yang cenderung extrovert memiliki kompetensi pribadi dan keterampilan yang lebih tinggi dibandingkan dengan mereka yang introvert. Hasil ini menunjukkan bahwa orang yang bertipe extrovert memiliki kecenderungan untuk bersosialisasi lebih tinggi daripada mereka yang introvert sehingga akan memudahkan bagi konselor untuk menjalin hubungan interpersonal yang berkualitas dalam proses konseling. Sementara itu, kecenderungan orang introvert adalah sebaliknya. Dengan kecenderungan pribadi yang extrovert, orang cenderung lebih mudah membuka diri atau mengungkapkan emosi. Eksplorasi diri merupakan bagian yang sangat penting bagi seorang konselor sehingga ia akan mengenali dirinya dengan lebih baik dan kemudian mampu mengenali keadaan psikologis orang lain sehingga akan membuatnya mampu berempati, menghargai, dan memahami konseli. Kecenderungan extrovert nampak memiliki fungsi yang sama karena kebutuhan orang extrovert akan orang lain dapat membantu seseorang untuk mengembangkan keterampilan dan kompetensi dalam menjalin terapeutic relationship.
Selain kompetensi pribadi dan keterampilan, mahasiswa tidak memiliki perbedaaan pada sisi pengetahuan dan profesional. Dengan memperhatikan latar belakang, kurikulum, dan tingkat semester mahasiswa, hasil ini terhitung logis karena pada semester 4 dan 6 mahasiswa masih sama-sama menempuh perkuliahan yang bersifat pengetahuan dan penguasaan keterampilan dasar dan belum mengalami praktik langsung di lapangan seperti KKN dan PPL. Praktik baru akan dilakukan pada semester 7. Sementara itu, aspek pribadi masih merupakan aspek yang tidak memperoleh perhatian khusus di dalam kurikulum sehingga perbedaan kualifikasi pribadi menjadi wajar bagi para mahasiswa. Selain itu, aspek keterampilan mahasiswa memiliki perbedaan yang tidak begitu signifikan. Ada kemungkinan hal ini diakibatkan karena adanya mata kuliah praktikum yang sudah diambil oleh sebagian dari mereka dan ada yang masih belum bisa mengambil mata kuliah praktikum.

Kedua, pada tipe kepribadian lain selain arah pemusatan perhatian, tidak ditemukan perbedaan yang signifikan dalam kaitannya dengan kompetensi para mahasiswa yang terlibat dalam penelitian. Perbedaan yang tidak nampak signifikan ini dapat diakibatkan oleh capaian mahasiswa yang belum menempuh seluruh 
mata kuliah yang diacukan kepada kompetensi akhir sesuai dengan permen nomer 27 tahun 2008 atau standar kompetensi konselor Indonesia. Selain itu, dapat pula bahwa alat ukur yang digunakan masih perlu penyesuaian karena pada dasarnya berbeda budaya dengan alat ukur itu berasal yaitu Amerika Serikat. Kemungkinan lain yang dapat terjadi adalah adanya ketidakselarasan antara alat ukur kompetensi konselor dengan desain kurikulum yang berbasis pada permen nomer 27 tahun 2008 dan atau standar kompetensi konselor Indonesia. Alat ukur kompetensi yang digunakan dikembangkan berasarkan pengukuran kompetensi konselor sekolah di Amerika (American School Counselor Association) sementara pencapaian mahasiswa belum setara dengan kualifikasi konselor profesional di Amerika. Para konselor di Amerika mendapatkan sertifikasi profesional setelah menempuh program Counselor Education setingkat Magister, sementara di Indonesia keberadaan program profesi masih terbatas sehingga untuk dapat memberikan layanan konseling seseorang dapat menggunakan kualifikasi akademiknya yang masih sarjana.

Terlepas dari ada dan tidaknya perbedaan tipe kepribadian dalam kaitannya dengan kompetensi yang dikuasai mahasiswa, jenis keilmuan Bimbingan dan Konseling itu sendiri perlu mendapatkan perhatian khusus. Secara historis, Bimbingan dan Konseling berasal dari Negara Barat yang secara budaya berbeda dengan Indonesia. Bidang ilmu konseling berkembang dari budaya Eropa yang kemudian berperan penting dalam perkembangan teori, penelitian, dan praktiknya. Ada tiga karakteristik khas dari budaya European American yaitu individualisme, otonomi, dan etnosentrisme yang mendominasi sumber-sumber pustaka konseling yang terbatas kesesuaian dan penerapannya pada budaya yang berbeda.

Faktor kepribadian telah lama menjadi salah satu fokus dalam mengkaji kualitas atau kompetensi konselor. The Sixteen Personality Factor Questionnaire (16PF) digunakan untuk mengidentifikasi kepribadian konselor. Selanjutnya, konseli yang pernah memperoleh layanan konseling kepada konselor yang terlibat diminta untuk memberikan skala berkaitan dengan "unconditional positive regard," "emphatic understanding," "congruence," dan "trust" dengan the Relationship Inventory. Dari penelitian itu diperoleh hasil yang signifikan hubungan antara empat faktor kepribadian dan tiga variabel hubungan. Penelitian itu menunjukkan bahwa perhatian terhadap performa dalam melakukan konseling yang efektif telah dipelajari sejak lama di negara barat terutama di Amerika.

Selain hubungan kepribadian dengan fungsi konseling yang dirasakan oleh konseli, Sumari, Mohammad, dan Ping (2009:02) telah melakukan penelitian yang fokusnya lebih spesifik yaitu tentang tipe kepribadian dalam kaitannya dengan preferensi orientasi teori konseling. Dalam jurnal yang ditulisnya, dipaparkan bahwa sejumlah peneliti telah meneliti faktor-faktor yang menentukan orientasi konseling pada konselor. Hasil penelitian menunjukkan berbagai faktor seperti nilai, kepribadian, dan orientasi supervisor mempengaruhi pilihan terhadap orientasi teori konseling. Beutler dan McNabb (1981:398) menyatakan bahwa para konselor magang/pratikan cenderung mengadopsi orientasi teori supervisornya.

Berbagai penelitian terdahulu menunjukkan bahwa tipe kepribadian berkontribusi pada pilihan orientasi teoritis para konselor (Sumari, Mohammad, dan Ping, 2009:98). Banyak pengukuran telah dilakukan untuk mengetahui kepribadian dan orientasi teoritis. Sayangnya, kebanyakan penelitian dilakukan di negara barat seperti Amerika dan Inggris demikian juga dengan orientasi teoritis dikembangkan para peneliti berkebangsaan barat yang mana mereka juga lahir dan tumbuh besar di negara dan budaya barat. Akibatnya, 
mahasiswa program konseling yang tumbuh atau besar di daerah dan budaya lain bisa mengalami proses yang lebih sulit karena asingnya teori-teori konseling bagi mereka .

Varlami dan Bayne (2007:364) meneliti tentang tipe psikologis dihubungkan dengan oritentasi teori pada mahasiswa magang psikologi konseling di Inggris. The Kersey Temperament Sorter II dan sebuah kuesioner demografis pendek digunakan dalam penelitian ini. Hasilnya menunjukkan bahwa para pratikan yang memiliki kepribadian Sensing-Judging lebih memilih model perilaku kognitif, Intuition-FeelingJudging memilih model psikodinamik, dan kepribadian Intuition-Feeling-Perceiving memilih model person-centered. Pada penelitian Dodd dan Bayne (2006:105) ditemukan adanya hubungan antara pilihan orientasi teori cognitive behavioral dan Sensing dan Judging, Psikoanalisis dan jenis Intuition dan Feeling dan Introvert, Intuitive, Feeling, dan Judging. Tipe Psikosintesis memilih Feeling dan Perceiving, dan Introvert, Intuitive, Feeling, dan Perceiving. Sementar itu, bagi mereka yang berorientasi eklektik atau campuran cenderung extrovert dan intuitif.

Orientasi teori konseling dan kecenderungan kepribadian merupakan bagian dari ketentuan kualitas profesional seorang konselor di dalam permen nomer 27 tahun 2008 selain kompetensi pedagogik dan sosial. Keduanya berhubungan saling berkaitan walaupun menurut penelitian yang pernah dilakukan di Malaysia oleh Sumari, Mohammad, dan Ping, (2009:102) menunjukkan bahwa tidak ada perbedaan orientasi teori diantara mahasiswa yang sedang menjalani magang melakukan layanan konseling dilihat berdasarkan tipe kepribadian mereka. Menurut analisis yang lebih mendetail, para subyek yang berasal dari budaya timur masih mengalami kendala perbedaan budaya pada instrumen yang digunakan sehingga masih terdapat kemungkinan hasil yang belum akurat.

Untuk dapat memberikan layanan konseling yang efektif, konselor perlu memiliki kompetensi yang efektif pula. Selain penelitian ini yang mengkaji sisi kecenderungan tipe kepribadian konselor, dalam lingkup yang sejalan dikenal dengan adanya konselor efektif. Beberapa ahli telah mengklasifikasikan karakteristik efektif yang perlu dimiliki konselor. McLeod (2013:134) merinci area kompetensi konselor efektif meliputi: keterampilan interpersonal, keyakinan dan sikap pribadi, kemampuan konseptual, kesehatan pribadi, penguasaan teknik, kemampuan untuk memahami dan bekerja dalam sistem sosial, keterbukaan terhadap pembelajaran dan pengetahuan baru.

Berkaitan dengan kompetensi konselor efektif ini, kemampuan interpersonal merupakan aspek kompetensi yang berperan dalam membantu hubungan interpersonal yang produktif dengan klien. Kemampuan sesuai dengan karakteristik orang yang cenderung extrovert. Dengan kemampuan interpersonal yang kuat atau extrovert, konselor akan mampu menjalin hubungan terapeutik dan sangat dibutuhkan bagi berbagai (sebagian besar) pendekatan konseling dan untuk menyelenggarakan layanan konseling efektif (McLeod, 2013: 35).

Melalui penelitian ini, diketahui bahwa arah pemusatan perhatian mahasiswa Bimbingan dan Konseling berbeda dilihat dari aspek kompetensi pribadi. Maka dari itu, perlu diperhatikan bagaimana calon konselor yang cenderung introvert dapat menjadi konselor yang efektif. Walau ada kemungkinan kendala lintas budaya atau keterbatasan instrumen dalam menjelaskan perbedaan budaya subyek penelitian maupun jenis keilmuan, penekanan pada sisi pendidikan konselor akan sangat membutuhkan bagian pemahaman pribadi ini. Dengan demikian, mahasiswa dapat mempersiapkan dan menyesuaikan diri untuk mencapai kualifikasi konselor 
visi kepala sekolah, motivasi kerja guru dan iklim organisasi secara bersama-sama terhadap kinerja guru sebesar 59,6\% dan sisanya dipengaruhi variabel lain.

Secara bersamaan ketiga variabel baik itu manajemen supervisi kepala sekolah, motivasi kerja guru dan iklim organisasi memberikan andil yang signifikan terhadap kinerja guru. Sekolah yang di dalamnya terdapat kepala sekolah yang melakukan supervisi dengan baik, disertai guru-guru yang memiliki motivasi kerja tinggi, dan iklim organisasi sekolah yang baik mampu secara efektif meningkatkan kinerja guru.

\section{PENUTUP}

\section{Simpulan}

Dari hasil analisis data dan pembahasan, maka dapat disimpulkan bahwa 1) Manajemen supervisi kepala sekolah berpengaruh positif dan signifikan terhadap kinerja guru di Sekolah Dasar Kecamatan Wonosari, Kabupaten Gunungkidul. yang ditunjukkan dengan kontribusi sebesar 39,3\%. 2) Motivasi kerja guru berpengaruh positif dan signifikan terhadap kinerja guru di Sekolah Dasar Kecamatan Wonosari, Kabupaten Gunungkidul dengan kontribusi sebesar 31,7\%. 3) Iklim organisasi berpengaruh positif dan signifikan terhadap kinerja guru di Sekolah Dasar Kecamatan Wonosari, Kabupaten Gunungkidul dengan kontribusi sebesar 41,1\%. 4) Manajemen supervisi kepada sekolah, motivasi kerja guru dan iklim organisasi secara bersama-sama berpengaruh positif dan signifikan terhadap kinerja guru di Sekolah Dasar Kecamatan Wonosari, Kabupaten Gunungkidul dengan kontribusi sebesar 59,6\%

\section{Saran}

Berdasarkan kesimpulan hasil penelitian, beberapa saran yang diajukan yaitu: 1) Pelaksanaan supervisi diharapkan lebih efektif agar tidak hanya sekedar memenuhi syarat administratif atau sekedar melaksanakan tugas, saran yang diusulkan adalah dalam melaksanakan supervisi diprogramkan secara sistematis sehingga setelah kegiatan supervisi akan lebih efektif dan selalu berkelanjutan. 2) kepala sekolah selalu mendukung guru yang ingin selalu meningkatkan kariernya, dan memberikan dorongan atau motivasimotivasi kepada guru yang berpedoman hanya melaksanakan tugasnya sebagai guru, memuji pekerjaan yang berhasil dengan memuaskan dan membantu bila ada guru yang mengalami kesulitan dalam pekerjaan. 3) Kepala sekolah tidak segansegan memberikan penghargaan secara langsung baik melalui ucapan selamat maupun memberikan pujian kepada guru yang berprestasi, kepala sekolah memberikan kepercayaan kepada guru bila sedang melaksanakan pekerjaan.

\section{DAFTAR PUSTAKA}

Anang, Z. (2012). Uji Kompetensi Guru Jauh dari Standar. Diakses dari http://www.tempo.co/read/ news/2012/08/06/079421605/Nilai-UjiKompetensi-Guru-Jauh-dari-Standar pada tanggal 10 Desember 2012.

Asmani, J.M. (2009). Manajemen Pengelolaan dan Kepemimpinan Pendidikan Profesional. Yogyakarta: Diva Press.

Bank Dunia \& Pusat Penelitian Kebijakan Badan Penelitian dan Pengembangan Kemendiknas. (2010). Ringkasan Eksekutif Studi Kemangkiran Guru. Diakses dari Http://www.guru-indonesia. net/./f_8994_STUDI KEMANGKIRAN GURU 2010 pdf. Pada tanggal 8 Nopember 2013.

Barnawi \& M. Arifin. (2012). Kinerja Guru Professional: Instrument Pembinaan, Peningkatan, dan Penilaian. Yogyakarta: AR-RUZZ MEDIA.

Bush, T \& Coleman, M. (2000). Leadership and Strategic Management in Education. London: Paul Chapman Publishing Ltd. 
Farmer, B.C. (1996). A Nursing Home and Its Organizational Climate.Westport: Greenwood Publishing Group, Inc.

Muslim, S.B. (2010). Supervisi Pendidikan Meningkatkan Kualitas Profesionalisme Guru. Bandung: CV. Alfabeta.

S. Sagala. (2004). Manajemen Strategic dalam Peningkatan Mutu Pendidikan: Pembuka Ruang Kreativitas, Inovasi dan Pemberdaayaan Potensi Sekolah dalam Sistem Otonomi Sekolah. Bandung: Alfabeta.

S.P. Siagian. (2004). Teori Motivasi dan Aplikasinya. Jakarta: PT. Rineka Cipta. (2006). Manajemen Sumber Daya

Manusia. Jakata: Bumi Aksara
Sri Andari. (2011). Hasil Pemantauan terhadap Kepala Sekolah SD Wonosari. Wonosari: Laporan.

Suharsimi Arikunto. (2013). Dasar-dasar Evaluasi Pendidikan. Jakarta: PT. Bumi Aksara.

. (2006). Prosedur Penelitian: Suatu Pendekatan Praktik. Jakarta: PT. RinekaCipta.

(2004). Dasar-dasar Supervisi. Jakarta: PT. Rineka Cipta.

Yonghon, Cai \& Lin Chongde. (2006). Theory and Practice on Teacher Performance Evaluation. China: Higher Education. 